\author{
Anna Marciszewska \\ Wrocław University of Economics \\ e-mail: anna.marciszewska@ue.wroc.pl
}

\title{
STRUCTURAL FUNDS AND DEVELOPMENT OF NON-PROFIT ORGANISATIONS
}

\begin{abstract}
Summary: The article contains theoretical considerations connected with the influence of structural funds on the development of non-profit organisations. Theoretically, the access to these funds should ensure development of these entities. However, as practice shows it is not always the case. We observe development dynamics of this sector and constantly unused social potential. These organisations are subject to continuous pressure directed towards full use of their resources and growth in effectiveness of activities undertaken. However, the pace of their development is mainly dependent on funds allocated for their development, therefore it seems legitimate to financially support activities of non-profit organisations from, inter alia, structural funds. These resources enable to earn experience which positively affects their development. However, the success of majority of non-profit organisations is not based on the structural funds. Managing persons are very careful during a process of acquiring, implementing and accounting for EU-supported projects. They think that this process is not always successful. The article draws attention to the fact that structural funds can be a key for development of non-profit organisations, yet provided that applying for financial support will not be accidental and will constitute an organised sequence of activities.
\end{abstract}

Keywords: non-profit organisations, structural funds, EU projects.

DOI: $10.15611 / \mathrm{e} 21.2014 .4 .09$

\section{Introduction}

Non-profit organisations ${ }^{1}$ are being confronted with the necessity of implementing many new tasks. It translates into the importance of acquiring larger resources (both financial and non-financial) which use requires greater knowledge and competencies of managing persons, directed towards the effective management of owned resources. For the most part these entities run service activity which task is to satisfy human needs. Therefore it contributes to calling non-profit organisations as social

${ }^{1}$ The Act defines non-profit organisations as "not being units of the public finance sector, as defined by the regulations on public finance, and not acting to generate profit, legal persons or units not having legal personality established pursuant to provisions of acts, including foundations and associations" - Article 3(2) of the Act of 24 April 2003 on public benefit activity and voluntary service. 
organisations. As opposed to commercial institutions, they act in public, not private, interest. Compared to other organisations, they are distinguished by high self-reliance in providing social services and autonomy of action, being a factor which makes it possible to respond to social needs and improve operating procedures [Czuba 2005, p. 27]. Currently, we can observe large diversity of organisations operating in the third sector with simultaneous dynamics of their development and constantly unused social potential. These are more complex, more flexible and having different values and motivation for acting than the so-called business entities. In addition, diversified components and shareholders are managed in them (managers, supervisory board, local community representatives, volunteers, sponsors, donors, business partners, etc.), which translates into the necessity of connecting all of these elements together and achieving objectives completely different than the business ones. Funds in this case become a measure to implement objectives, and are not the objective. It is for this reason recommended that non-profit organisations should be managed by clairvoyant managers having ability to concentrate on strategic objectives, mission integrity and aspirations to make the best decisions in terms of quality [Czuba 2005, p. 27]. In order to make it possible for non-profit organisations to survive and implement their objectives effectively, they must continually develop and change management methods. It is therefore very important to manage them taking into consideration culture, mission and public image of these organisations. The basis for efficient functioning of non-profit organisations is effectiveness (a measure of the degree of implementation of objectives) and cost-effectiveness (a measure of the degree of expenses incurred for objectives being implemented). It means that a subject which implements objectives assigned to it and rationally manages resources of the organisation shall be deemed efficient. However, with respect to the entities being discussed it should be underlined that efficient operation is not only implementing objectives and rational managing resources, but above all, it is determining adequate objectives of operation resulting from actual needs of potential customers (and not organisations) - taking into consideration their scale and hierarchy [Czuba 2005, p. 28]. The pace of development of non-profit organisations is dependent on funds being allocated for their development. The role these entities perform in the social development is a justification of the necessity of supporting financially this sector. Limited possibilities of operation result, above all, from staff, housing and equipment shortages and often from low-qualified employees and volunteers, and from restricted access to specialist services. It is yet indicated in the literature concerning the subject that there is a small, but strong group of non-profit organisations which underwent the process of professionalization and is a strong pillar of it, being at the same time the source of examples of good practices [Przybylska-Maszner 2009, p. 19]. Changes observed in these organisations are caused, inter alia, by a change of attitudes of leaders towards more rational business models in organisations and their self-education. Basic development processes of this sector are [Gliński, Palska 1997, p. 34]: 
1. institutionalisation (a process of transformations of forms of activities of the organisation),

2. development of an information and communications network inside and outside the sector,

3. development of contacts with the environment (with the national sector, with self-government administration, with business, with mass media, with scientific institutes, with universities, with foreign organisations, with other non-profit organisations),

4. professionalization of activities of social entities (i.e. extending professional and organisational knowledge),

5. development of service and support institutions for non-profit organisations.

Progressive development processes of non-profit organisations are a strong argument supporting increasing the role of structural funds in the process of partially funding their activities. When analysing past experience of these entities a thesis can be hazarded that structural funds can contribute to the development of non-profit organisations in Poland, but provided that persons managing or working in these organisations gain adequate knowledge allowing to acquire EU funds.

The purpose of this article is to demonstrate considerations being an attempt to answer the question whether or not and to what extent the availability of structural funds by non-profit organisations affects their development. Due to a small number of publications in this area it seems legitimate to enter into this subject. The article should at least to a small degree contribute to fill this gap.

\section{Structural funds, and non-profit organisations}

The purpose of structural funds is to support restructuring and modernising the EU countries economies, in order to increase economic and social cohesion as part of the whole Community. However, in order to make it possible to take advantage of these resources, each of the Member States of the EU must prepare strategic documents taking into consideration guidelines which in detail define national priorities and areas, for which the EU and national resources are allocated in particular programming periods ${ }^{2}$. Previously Poland was included by the support in the programming period 2004-2006 ${ }^{3}$ and 2007-2013 [Domiter, Marciszewska 2013, pp. 28-29]. The budget for the period 2014-2020 is currently binding. Structural funds in this period are allocated in Poland pursuant to the Partnership Agreement adopted by the Council of Ministers on 8 January 2014 and accepted

\footnotetext{
${ }^{2}$ Budget of the European Union is planned in multiannual periods. It is a 7-year period being the basis to apply for support on the part of the European Commission.

${ }^{3}$ Poland acceded to the European Union on 1 May 2004, therefore in the programming period 2000-2006 it was included by support from structural funds in the period 2004-2006.
} 
by the European Commission on 23 May 2014. This document demonstrates conditions and legitimacy for use of structural funds by Poland in the period 2014-2020. It contains an analysis of developmental needs of Poland as well as objectives and priorities for activities in thematic and territorial perspective together with basic indicators of implementation. It is connected with the requirements of the European Commission, the Europe 2020 Strategy and the developmental objectives of Poland for the coming years. Pursuant to the adopted Partnership Agreement, spending structural funds is based on more detailed documents, i.e. Operational Programmes (PO), in which both thematic, and territorial priorities are defined [Europejskie bezzwrotne... 2012, pp. 44-46]. These programmes define specific support areas and implementation instruments. In the new perspective, the Partnership Agreement is implemented by means of seven operational programmes (PO) managed by the Ministry of Infrastructure and Development and by means of sixteen regional operational programmes (RPO) managed by boards of directors of individual voivodeships. Among the operational programs of which the Partnership Agreement is composed, the following can be mentioned [Umowa Partnerstw 2014]:

1. Infrastructure and Environment Operational Programme (PO IŚ) - the main purpose of the programme is to efficiently support the economy using the resources, as well as environmentally friendly and supporting territorial and social cohesion.

2. Intelligent Development Operational Programme (PO IR) - the main purpose of the programme is to support innovation and competitiveness of the Polish economy, being expressed mostly by increase in expenditures for R\&D.

3. Knowledge Education Development Operational Programme (PO WER) the programme was created in response to the needs for reforms in the fields of employment, social inclusion, education, higher education, health and good management. It was directed towards supporting social innovations and transnational cooperation in the mentioned areas and implementation the Initiative for Youth Employment in Poland.

4. Digital Poland Operational Programme (PO PC) - the main purpose of the programme is to enhance digital foundations for social and economic development of the country.

5. Eastern Poland Operational Programme (PO PW) - the purpose of the programme is to increase competitiveness and innovation of the macro-region of Eastern Poland (i.e. Lubelskie Voivodeship, Podlaskie Voivodeship, Podkarpackie Voivodeship, Świętokrzyskie Voivodeship and Warmińsko-Mazurskie Voivodeship).

6. European Territorial Cooperation Operational Programme (PO EWT) and European Neighbourhood Instrument (EIS) - programme assumptions concern cooperation in the cross-border, transnational and interregional dimension.

7. 16 regional operational programmes (RPO) - the main purpose of the programmes is to increase the competitiveness of particular regions and to promote sustainable development. 
8. Technical Assistance Operational Programme (PO PT) - this program guarantees financial resources to handle the implementation process of the cohesion policy of the European Union in Poland in 2014-2020.

Previous, ten-year experience of non-profit organisations in taking advantage of structural funds is connected with the implementation of approximately 12.5 thousand projects included by the EU subsidy, of a total value of more than PLN 10 billion. It is estimated that $27 \%$ foundations and associations submitted applications for financial support from the EU funds until 2012, while $12 \%$ of them received the support. It should be yet noted that organisations that at least once attempted to acquire the EU support were becoming more and more active in applying for these resources [Teisseyre 2014]. Research carried out by Stowarzyszenie Klon/Jawor indicates that as much as $64 \%$ of projects being implemented by non-profit organisations included by the EU support concerned the development of human capital. The implementation of this design undertaking was connected with widely-understood activities directed towards counteracting unemployment, broadly understood education or professional activation. These projects aimed both to aspire to system changes, and to help specific groups of beneficiaries. On the second place undertakings $(20 \%$ of the EU projects implemented) were directed towards innovations and entrepreneurship. They were mainly implemented by organisations supporting entrepreneurship, science and local and regional development. Third place was occupied by projects connected with tourism and culture (approx. 3.9\% of the value of the EU projects implemented by non-profit organisations). Next groups of projects were connected with environmental protection, social infrastructure development, such as building, extending or equipping kindergartens, schools, health centres, hospices or care centres for the disabled. The participation of non-profit organisations in other areas was very low. Implemented projects were above all connected with the development of information society, increase in energy efficiency, expansion of alternative sources of energy, revitalisation of cities, villages and transport [Podstawowe fakty... 2013].

When analysing the above data, it can be seen that the participation of non-profit organisations in taking advantage of available structural funds was first of all visible in implementing projects directed towards the development of human capital. Within this area, $12.5 \%$ of the values of all investments were activities undertaken by non-profit organisations. The activity of the organisations discussed can also be observed in undertakings directed towards the development of tourism and culture $(2.1 \%$ as compared to all of the projects which were implemented in this area), innovation and entrepreneurship (1.6\%) as well as social infrastructure (1.2\%). In other areas this participation was marginal [Podstawowe fakty... 2013].

It is thus worth discussing limitations connected with the access of non-profit organisations to structural funds. As shown in the report drawn up by the Association for the Forum of Non-Governmental Initiatives, the following can be mentioned among the major ones [Kolankiewicz, Komorowska, Wasilewska 2008, p. 81; Podstawowe fakty... 2013]: 
- Personnel - non-profit organisations are entities in which people employed on the basis of civil-law contracts are missing. It is one of the conditions for creating project teams in undertakings included by the EU subsidy. These organisations are characterised by employing people to the project only after they have received financial support. It contributes above all to delays at the initial stage of the project implementation, lack of time to build the team and the personnel policy of the organisation. The method for applying for the EU subsidy requires at the project planning stage to indicate the team structure and the management methods. Furthermore, organisations become employers which is connected with the necessity to change the method the organisation is managed. The implementation of the EU projects requires great skills and knowledge. Accounting for the project is connected with submitting on the dates designated the so-called applications for payment. As part of these documents appropriately prepared personnel documents are required, such as contracts, ranges of responsibilities, payrolls, work records, etc. Every mistake causes delays in payments. Non-profit organisations have problems with professionalization in this respect. However, it should be emphasised that spending public funds is connected with both reliability of their spending, and keeping documentation in a clear manner, consistent with rules and laws applicable in the country.

- Annual budget of the organisation - from the past experience it results that organisations which annual budget is more than PLN 30 thousand have the possibility to apply for the EU support. Non-profit organisations which annual budget exceeds PLN 100 thousand dominate among the non-profit organisations implementing the EU projects. It results above all from the assumption that the entity which so far has been dealing in significantly smaller sums, would not be able to cope with larger financial resources, especially with the necessity involved in documenting expenses in such a detailed manner. It was for this reason justified to introduce possibilities to account for some expenses by means of the so-called flat rates. But even such a solution does not make it easier for many organisations to apply for the EU support.

- Accounting - requirements connected with the obligation to reliably document the expenses in the EU projects cause the necessity to keep professional accounting. It forces not only to employ a person with adequate qualifications, but also with adequate knowledge about the specificity of the EU projects. As it is shown by research in this area [Podstawowe fakty o organizacjach pozarzadowych 2012, 2013 ] this condition is satisfied by fewer than $60 \%$ of organisations, $17.6 \%$ of entities do not keep accounting books at all and $25 \%$ do it in an irregular manner. It therefore contributes to excluding organisations at the stage of applying for the EU funds, and the lack of professionally drawn up application for payment (a financial statement) limits access to next subsidies tranches. However, it should be emphasised that the budget of this type of projects assumes the possibility to cover this type of services as part of the so-called indirect costs of the project. 
It seems for this reason more legitimate to indicate the presence of barriers in the method of thinking itself and the lack of willingness to change it by people managing the organisation. It can be yet observed that year by year this situation has been improving.

- Type of activities included by the EU support - one of the access criteria to structural funds is to undertake statutory activities in the area included by objectives of a given competition. However, from the point of view of the method of functioning of non-profit organisations and their flexibility as regards carried out activities and aiming at solving present social problems, it becomes a problematic issue. It is difficult for organisations to adapt in terms of their activities to areas included by the EU support. It is for this reason recommended that these entities demonstrated greater involvement at the stage of consulting the programme documents. Lack of this activity contributes to implementing tasks indicated by the administration, which not always coincides with local expectations and needs. It often results simply from the lack of knowledge on the part of the administration and the lack of comments on the part of non-profit organisations during public consultations. This limitation can only be eliminated in the case of greater involvement of these organisations in public consultations at the stage of planning different activities as part of structural funds.

- Bank account - a condition appearing when handling design undertakings funded from the EU funds is to have the bank account. It is recommended that most settlements are made via a bank account which should be separated for the purposes of implementing a specific project. In this case a problem often appears connected with maintaining such an account as well as with the access to the bank offer satisfying expectations of non-profit organisations. Currently, it is limitation which can be the most easily eliminated, taking into account the possibility to finance the cost of maintaining the bank account from the support received from the European Union.

The assessment of non-profit organisations, from the point of view of their activity in taking advantage of structural funds, is not too high. These are entities which have many good ideas, energy and initiative, which could translate into the implementation of high-quality projects. Unfortunately, in the last programming period 2007-2013 such an activity still did not exceed 15\%. The general tendency of most of the programmes is to simplify procedures and facilitate application as far as possible. However, even in this situation these rules are still too stiff, not taking into consideration the specificity of non-profit organisations. It is for this reason adequate content-related support which becomes so important in the application process for these entities. There are many entities or specialists helping in applying for structural funds in Poland. Non-profit organisations can take advantage of numerous support and information systems developed specifically for them. Yet, the main source of knowledge about the EU resources is the Internet. Furthermore, these organisations, just like other entities, may obtain help in a few dozen regional centres 
of the European Social Fund and information points operating in each implementing institution. A rich offer of chargeable help can be also provided by consulting companies. However, data are missing indicating to what extent the advisory support received affects obtaining a subsidy for the implementation of specific projects. Yet, professional help certainly increases a chance to receive the EU support.

\section{The role of structural funds in the development of non-profit organisations}

Availability of structural funds should contribute to increasing efficiency and effectiveness of activities of particular non-profit organisations. Financial support of the EU projects being implemented by these entities is also directed towards developing and creating networks of cooperating organisations, also including self-governments, which are responsible for the implementation and provision of social services. As part of available resources, it is additionally assumed to implement activities concerning selected areas of social policy, key from the point of view of the Europe 2020 strategy and national reforms programmes. Structural funds are an essential source of financing undertakings in the areas of widely understood local and regional development. Therefore absorption of proposed forms of support should be important for these entities [Wojtach 2014].

In non-profit organisations a change should occur in an attitude to the implementation of design undertakings because they play an important role in the absorption process of the EU funds. Processes supporting these activities are managing employees' knowledge and experience, precise division of duties, rights and responsibilities at all workplaces or cooperation of teams. It should be furthermore remembered that some difficulty for non-profit organisations can be the fact that applying for and awarding a subsidy for design undertakings implemented by the beneficiaries of the EU funds, including non-profit organisations, is regulated in the form of numerous legal acts in the form of EU regulations concerning the implementation of particular funds, the act on the principles of the development policy, the act on the public finance and documents in the form of guidelines of the managing institutions or contests regulations. In non-profit organisations, the process of preparing and implementing a project usually does not proceed according to previously internally drawn up orders or instructions. It causes that past experience of these organisations in obtaining the EU funds indicates their low participation. It can be for this reason attempted to claim that non-profit organisations to an unsatisfactory extent participate in the process of obtaining structural funds. Therefore further simplifying and liberalising national regulations and procedures shall be necessary in this area [www.funduszeeuropejskie.gov.pl].

However, from the point of view of implementing assumptions of the structural funds non-profit organisations above all become a part of implementing activities directed towards, inter alia, delivering social services, social integration (in 
particular in questions concerning availability of the labour market for people at risk of social exclusion or socially excluded and counteracting exclusion) and integrated development of local communities. A feature distinguishing discussed non-profit organisations from other beneficiaries of structural funds is their flexibility as regards responding to social problems and the role they play in shaping entrepreneurial attitudes for social purposes [Przybylska-Maszner 2009, p. 22]. Entities applying for the EU support are above all training and consulting organisations, the objective of which is to implement statutory objectives, and not to generate profits. These institutions as potential project initiators dominate in undertakings financed from the European Social Fund (EFS). They are distinguished by an ability to act for the benefit of specific groups. Beneficiaries of activities of these organisations are, among others, teenagers, disabled, long-term unemployed, women, inhabitants of rural areas, refugees or national minorities. Due to such features as professionalism, innovation, flexibility of activities and social involvement these organisations developed effective methods for working with disadvantaged groups. It is nothing else but specific competencies of non-profit organisations that are a strong argument supporting increasing their role in taking advantage of structural funds. It should be supposed that these non-profit organisations, as entities operating very often socially, should spend public funds intended for support of objectives consistent with their statutory objectives more effectively. In respect of activities as part of structural funds these are organisations which are much better familiarised with the needs of the target groups included by the support than other commercial institutions. Due to the nature of their activities, these organisations have real opportunities to affect, inter alia, increase in the employment level and the social cohesion.

However, examining the method the non-profit organisations are managed [Stowarzyszenie Klon/Jawor 2013], it can be observed that almost $40 \%$ of these organisations attempt to develop own human resources, re-organise institutionally, develop inter-institutional cooperation, especially as regards creating public-social partnership. These units demonstrate continuing needs as regards knowledge about the sources of financing and the opportunities of developing their organisations. Lack or an insufficient level and scope of these activities involves mainly high costs of this type of services, for which most of non-profit organisations, as organisations being based on a voluntary service and on a non-profit principle cannot afford financially [www. euroNGO.pl]. These organisations require adequate support which should be directed towards supporting building social background of these entities (professionalization of professional personnel and volunteers), enhancing financial and organisational stability, enhancing forms of cooperation of public administration, supporting research and expert background. This should lead to reinforcement of non-profit organisations, i.e. organisational and quality improvement should take place as regards internal potential, and externally a representative function should be reinforced [Przybylska-Maszner 2009, p. 24]. 
Reinforcement of non-profit organisations can contribute to their more effective participation in taking advantage of structural funds. One of the system solutions proposed is to create in the public finance system possibilities to finance investments, planned and implemented by these organisations, and connected with performing of the public tasks. This would contribute to financial security of non-profit organisations sector and would improve the quality of social services in the long term. It should also translate into the effectiveness of participation of non-profit organisations in projects implemented as part of available EU resources. [Przybylska-Maszner 2009, p. 30]. It should be yet emphasised that together with the enlargement of the European Union hopes increased that an inflow of structural funds shall contribute to a considerable improvement in institutional potential of non-profit organisations which in turn shall cause that these organisations shall become an important link in implementing the EU cohesion policy. However, after ten years of taking advantage of this support, it can be observed that most of non-profit organisations are still not ready to use these sources of funding of their activity. It is indicated that approx. $30 \%$ of the Polish non-profit organisations is in the group of project initiators having a real opportunity to apply for resources from the structural funds [Podstawowe fakty... 2013]. These entities most often belong to those which directed their activities towards creative responding to variability and needs of the environment, namely they opened to innovations. It allowed providing new services on "the social services market". Introduced changes can concern all activities of the organisation or only limit to selected areas of activity being carried out. However, the specificity of non-profit organisations causes that at the stage of testing the effectiveness of use of the EU funds by this type of organisations problems appear on the ground of selection of indicators of assessment criteria. In such cases the assessment is most often carried out from the point of view of quality tools. The analysis of effectiveness of implementation of hard-to-measure objectives is carried out by the descriptive comparing the results expressed with expectations and standards adopted in the procedure of applying for the EU funds. This all translates into a conclusion resulting from the carried out research demonstrated in the report "Non-Governmental Organisations, and Structural Funds", in which the authors draw attention to the fact that "structural funds are not intended and shall not be intended for reinforcing all non-governmental organisations, what is more, it shall never be the case that all non-governmental organisations shall be able to be their beneficiaries (...). The purpose for which the structural funds have been formed is simply different and concentrates on increasing competitiveness of the European economy in the world and ensuring socio-economic cohesion between the regions". 


\section{Structural Funds - opportunities and threats for development of non-profit organisations}

Non-profit organisations actively participate in recognising problems of the local environment and have the ability to voice them, and as a result also to satisfy them [Iwankiewicz-Rak 2011, p. 48]. However, in order to ensure social benefits of functioning of non-profit organisations they should be provided with financial support as regards activities being carried out. Structural funds can be one of such sources of financing in which a lot of organisations have put hope in. A lot of these entities counted that the funds shall provide them with the possibility to reinforce them institutionally and to raise their potential. Yet, the reality turned out to be disappointing for many of them. The main reason was connected with insufficient knowledge concerning the structural funds purposes, lack of the overlap with the areas of operations of most of non-profit organisations or lack of the potential which allowed applying for support on the terms and conditions specified in operational programmes. Research carried out in the discussed area indicates basic conclusions and recommendations concerning taking advantage by non-profit organisations of structural funds. The following are listed among them [Podstawowe fakty o organizacjach pozarzadowych 2012 2013, p. 249]:

- Necessity of carefully familiarising with competition documents and requirements. Many non-profit organisations at the stage of preparing the application for project financing are not familiar with the competition documentation and general principles required in a given competition. Managing persons it is often forgotten that the project implementation involves a large amount of additional administrative work, which is frequently connected with the necessity of employing a competent person responsible for formal questions. For some non-profit organisations it is a condition that cannot be accepted and then it turns out that the subsidy obtained can contribute to weakening non-profit organisations, not to its reinforcing.

- Preparation of non-profit organisations for project implementation. Implementing projects financed from structural funds requires employees, professional accounting, an account in the bank, a secured place for storing documentation, etc. However, it appears that for many non-profit organisations these are conditions which cannot be satisfied. Even the smallest project included by the EU support is too big a content-related challenge. The entities are recommended to earn design experience by implementing smaller and simpler design undertakings, e.g. in self-government competitions for the implementation of public tasks or in private organisations competitions.

- Diligent and realistic preparation of the project together with the budget. An important aspect at the stage of obtaining the EU support is a proper preparation of the application for project financing. It is important at this stage to check whether for example the undertakings proposed fall into a given activity, whether 
recipients of the proposed project are an authorised target group, if the objectives established refer to the diagnosed problems and needs, whether objectives, tasks and the schedule of the proposed activities are cohesive, etc. For people being in contact with projects, including the EU projects, it can seem obvious, yet for people responsible for these activities in non-profit organisations it is not always simple. Unfortunately, a lot of projects are prepared at the last minute, which usually results in the lack of cohesion between particular points described in the application for project financing. A lot of errors also occur at the stage of preparing the budget. The process of creating budgets itself is not difficult, yet most problems occur at the stage of eligibility check of some expenses or their underestimation or revaluation. Project initiators often forget that real costs are the costs corresponding to planned activities, taking into consideration all, even the smallest costs. The process of budgeting is not easy and unfortunately it is time-consuming. It is yet an essential point of assessment of the application and limitation of later problems connected with the tasks being implemented. A certain limitation is also the lack of possibility to qualify the cost connected with employing a specialist preparing the application as the design cost.

- Creating project teams with clearly specified tasks and responsibility. The implementation of the project included by funding from structural funds requires assigning appropriate employees for its implementation, creating a structure of the project team, making relevant division of tasks and determining responsibility for the implementation of particular work. Non-profit organisations are yet entities which activity is based on work of volunteers. These are persons involved in functioning of these organisations, but provided that they do what they like and what they are able to do best. Work in an organisation is often an additional occupation for them. Design undertakings impose on them the responsibility for spending public funds, which translates into great responsibility and laborious administrative work. It causes that these people are often not interested in cooperating on design rules. It is for this reason recommended to select people who shall understood the specificity of implementation of the EU projects. This shall make it possible to avoid organisational problems and later ones.

- Professional preparation of personnel with specific qualifications. The implementation of the EU design undertakings is connected with the necessity of ensuring a competent project team, which shall be able to both plan the project, implement it, and, what is important, account for it. For this reason issues connected with caring for personnel development, creating access to appropriate training courses and employment conditions are so important, allowing personnel to independently improve their skills and qualifications.

Most recommendations resulting from the report demonstrated concern for the stage of preparing the design undertaking according to the rules applicable in this area. However, a lot of non-profit organisations also report problems connected with the proper implementation of the design assumptions. For this reason ensuring 
adequate content-related support seems legitimate for organisations that obtained the EU support. Employees involved in implementing projects of this type show very large interest in improving their qualifications in this area. It is therefore important to provide them with an access to practical training courses within the scope of financial management, keeping accounting, personnel management, working using the design method as well as other which shall reinforce the potential of the organisation and make it be more professional in action. An interesting proposal can also be found in the literature concerning the support system of implementing mini-projects, namely education not by means of training courses, but by means of earning own experience. Working with the organisation at first when formulating the purpose, then when specifying the tasks and results which it wants to achieve until constructing the schedule and budget, seems to be the most effective support. Help for the organisation would also be important in obtaining such a mini-grant and then accompanying it at every stage of the project implementation. Going through such a cycle would certainly facilitate an organisation to reach "more difficult" money, being surely structural funds [Kolankiewicz, Komorowska, Wasilewska 2008].

It should also be noted that not all limitation is in favour of non-profit organisations. Among external factors the lack of simplification and decentralisation of the institutional system connected with management and implementation of structural funds in Poland can be mentioned as well as the lack of formulation of clear and detailed guidelines concerning both implementing the funds, and regulating the formal and financial side of implementation of the projects or the lack of possibility to fast introduce changes in situations when it is necessary and legitimate. Attention is also drawn to the quality of work of officials, and in particular to people having direct contact with the project initiators. It is important to ensure that these positions are occupied by competent employees. However, it often happens that people handling this type of undertakings have an insufficient level of qualifications and competencies to work. It causes that they are overburdened with work which, in turn, leads to high rotation, and this significantly affects efficiency and effectiveness of implementation of the projects.

Attempting to answer the question how structural funds affect development of an organisation and whether they are rather an opportunity for it or a threat a SWOT analysis can be carried out designed to indicate the impact of structural funds on the development of non-profit organisations (Tab. 1).

An analysis conducted above indicates that it is impossible to carry out an unambiguous assessment of influence of structural funds on development of non-profit organisations. An opinion by M. Gumkowska and J. Herbst should be mentioned who suggest to approach the issue of supporting development of non-profit organisations through the access to structural funds with reserve because "the purpose of spending these funds is to implement specific objectives of the EU policy, regardless of the role the non-governmental organisations play in it". Yet, at the same time, they rightly notice that "barriers making it difficult for organisations 
Table 1. Influence of structural funds on the development of non-profit organisations

\begin{tabular}{|c|c|c|}
\hline & POSITIVE & NEGATIVE \\
\hline 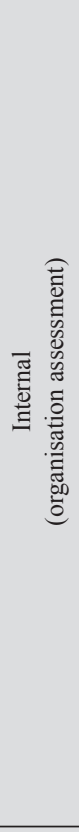 & 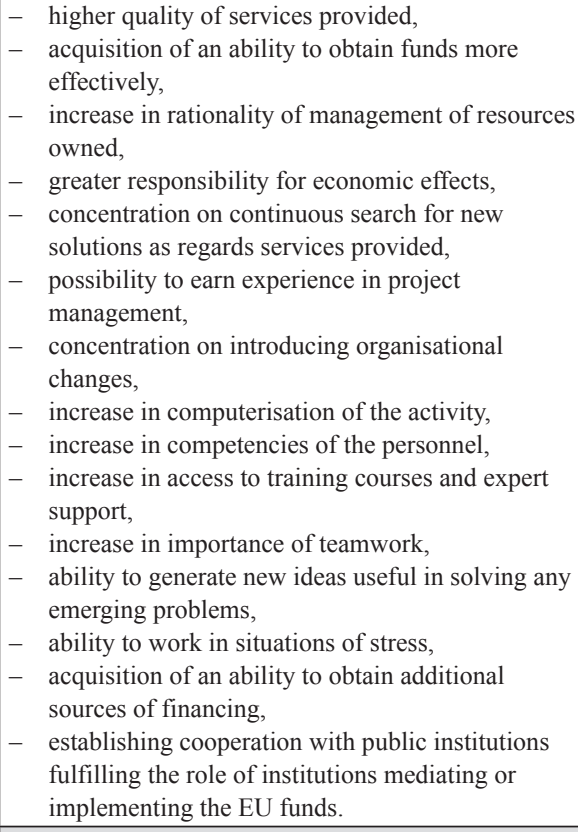 & $\begin{array}{l}-\quad \text { limited financial possibilities, } \\
-\quad \text { increased risk of design activities being carried } \\
\text { out, } \\
-\quad \text { dependence on entities financing the undertakings, } \\
-\quad \text { greater bureaucracy of activities, } \\
-\quad \text { greater demands as regards the personnel, } \\
-\quad \text { necessity of continuous improving skills and } \\
\text { acquiring new abilities, } \\
-\quad \text { problems as regards competencies of managing } \\
\text { persons, } \\
-\quad \text { adapting the type of activities undertaken to } \\
\text { competition guidelines, and not social needs, } \\
-\quad \text { too much time devoted to preparing the } \\
\text { application for project funding, } \\
-\quad \text { overburdening employees with design works, } \\
-\quad \text { limiting the work of volunteers in the case of } \\
\text { projects included by the support, } \\
-\quad \text { too much emphasis on design activities, which } \\
\text { can result in neglecting current activities of the } \\
\text { organisation, } \\
-\quad \text { failure to implement the project successfully } \\
\text { impairs further interest in structural funds, } \\
-\quad \text { increase in the rotation of current employees due } \\
\text { to the design experience earned by them. }\end{array}$ \\
\hline & OPPORTUNITIES & THREATS \\
\hline 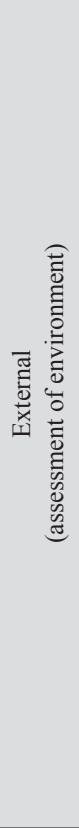 & $\begin{array}{ll}\text { - } & \text { taking advantage of non-profit organisations' } \\
& \text { potential, } \\
- & \text { interest of public administration in implementing } \\
& \text { common design undertakings, } \\
- & \text { taking advantage of experience of other } \\
& \text { institutions of so-called "good practices" } \\
- & \text { increase in employment in non-profit } \\
& \text { organisations, } \\
- & \text { creating quality standards of services provided, } \\
- & \text { active participation of the local community around } \\
& \text { organization's activities, } \\
- & \text { computerisation of the third sector, } \\
- & \text { reinforcement of a position of the non-profit } \\
& \text { organisations on the local and national market, } \\
- & \text { increase in interest in participating in public } \\
& \text { consultations, } \\
- & \text { access to qualified personnel, } \\
- & \text { integration of non-profit organisations, } \\
& \text { including the possibility to implement common } \\
& \text { undertakings, } \\
- & \text { possibility to establish international cooperation, } \\
- & \text { professionalization of non-profit organisations, } \\
- & \text { good knowledge of regulations and rules } \\
\text { concerning implementing structural funds in } \\
\text { Poland. }\end{array}$ & $\begin{aligned}- & \text { high competition in applying for EU funds, } \\
- & \text { lack of understanding of rules applying for the EU } \\
& \text { support, } \\
- & \text { breaking direct bonds of the organisation with the } \\
& \text { local community or the environment, } \\
- & \text { excessive professionalization leading to narrow } \\
& \text { specialisation of activities being implemented, } \\
- & \text { lack of interest on the part of other entities } \\
& \text { operating on the market in establishing } \\
& \text { cooperation with non-profit organisations, } \\
- & \text { increase in costs of functioning of organisation, } \\
- & \text { decrease in the number of volunteers, } \\
- & \text { lack of tradition of non-profit organisation in } \\
& \text { obtaining the EU support, } \\
- & \text { marginalisation of non-profit organisation due to } \\
& \text { the lack of relevant legal solutions for them, } \\
- & \text { hermetic language of design documentation, } \\
- & \text { lack of willingness to cooperate on the part of the } \\
& \text { public administration, } \\
- & \text { excessive formalisation of the process of obtaining } \\
& \text { the EU support. }\end{aligned}$ \\
\hline
\end{tabular}

Source: own elaboration on the basis of [Kolankiewicz, Komorowska, Wasilewska 2008; Podstawowe fakty... 2013]. 
to access the funds are not the barriers separating ineffective institutions from the effective ones, but the barriers separating powerful institutions from the small ones, the barriers between institutions sufficiently practised in the field of reporting and bureaucratic games, and those which are not sufficiently practised" [Kolankiewicz, Komorowska, Wasilewska 2008]. For this reason it seems legitimate for every factor, both positive and negative one, to be examined individually from the point of view of specified organisations and social interest.

Being based on to date results of the research carried out among non-profit organisations it should be emphasised that despite the lack of significant achievements in taking advantage of structural funds, these organisations in spite of many restrictions and weaknesses, are characterized by high potential allowing them to take advantage of this source of financing. High degree of involvement of non-profit organisations in undertaking many diversified activities, the effect of which is expanding resources of knowledge, allows to formulate favourable forecasts for the future. What worries is the decrease in the number of volunteers, worsening of the financial condition of small organisations as well as low degree of cooperation with other entities operating in a given region. Yet, examining opportunities which appear when taking advantage of structural funds it can be hoped that in so changing environment which is still establishing more and more demanding requirements in the field of tasks performed by non-profit organisations and access to new solutions, these institutions shall be able to develop and systematically reinforce their position on the market of social services. It should be yet remembered that in order to make the influence of structural funds on the development of these organisations "be felt", the following need to be fulfilled:

- these entities should develop and specialise in obtaining the EU support,

- units should be formed taking care of unlimited access of non-profit organisations to structural funds,

- a platform should be functioning for exchanging information and experience between non-profit organisations, directed towards mutual supporting and interacting.

When speaking about the development of non-profit organisations and their access to structural funds, it should be remembered to build a training and advisory offer adequate to up-to-date needs of non-profit organisations and to increase activity of these entities in improving skills and acquiring new knowledge and skills. These activities are furthermore connected with the professionalization process, which should not be seen as something bad and limiting the spontaneity of activities being undertaken by non-profit organisations. Professionalization connected with spending public money applies to all project initiators taking advantage of both structural funds, and state budget or self-governments funds. And therefore it should be seen as a principle in spending public funds on a legitimate purpose in a competent and clear manner. 


\section{Conclusions}

Taking into consideration the type of activities undertaken by non-profit organisations, an aspect of democratisation of life or quality of social services provided one should think whether such organisations shall satisfy requirements put in front of them as regards access to structural funds. It cannot be also forgotten that these organisations are acknowledged the most rapidly developing part of the socioeconomic activity of modern states. Various attempts are undertaken to develop new or to adapt already recognised concepts, management methods and tools taking into consideration specificity of these entities as well as their needs. Ability to obtain structural funds, and then to implement and account for the design undertakings can become an important asset of functioning of non-profit organisations. From the above considerations it results that this can also contribute to reinforcing strengths and taking advantage of opportunities arising from the environment, and become a recipe for most weaknesses and trouble with which non-profit organisations contend every day. Due to the effective use of access to structural funds these entities can substantially streamline the organisation and improve its efficiency which should contribute to authenticating activities undertaken in the eyes of stakeholders and translate into reinforcing both financial, and human resources [Domański 2012, p. 342].

The article discusses the influence of structural funds on the development of non-profit organisations. Opportunities and threats are indicated connected with access to structural funds and an answer is sought to the question, what conditions must be satisfied for Polish non-profit organisations to increase their effectiveness in obtaining EU support. Research available in the literature concerning the subject indicates that structural funds can become an opportunity for the development of non-profit organisations, but provided that:

- the potential of non-profit organisations is used,

- the personnel with specific qualifications is professionally prepared,

- the competition documents and requirements are diligently familiarised with,

- the organisation is prepared to implement the project,

- the project, budget and division of work are carefully and realistically prepared,

- it is enabled to earn design experience when implementing smaller projects,

- expert and training support is provided,

- reliable information can be accessed,

- cooperation with public and private institutions is established in order to earn experience, and also to implement public tasks.

Non-profit organisations are seen as involved project initiators which very often undertake touchy social problems. They distinguish themselves with very good knowledge of problems of target groups or conditions of local communities in which they operate. However, it should be remembered that for structural funds to contribute to developing non-profit organisations, representatives of local authorities, 
state administration, business and other stakeholders should be also involved in the process of obtaining, implementing and accounting.

\section{References}

Czuba M., 2005, Dylematy zarzadzania organizacjami non profit, [in:] Organizacje komercyjne i niekomercyjne wobec wzmożonej konkurencji i rosnących wymagań konsumenta, ed. A. Nalepa, Wyższa Szkoła Biznesu, Nowy Sącz.

Domański J., Zarządzanie strategiczne oraz jego modele dla organizacji non-profit, article published at http://wz.pw.edu.pl, [access 20.10.2012].

Domiter M., Marciszewska A., 2013, Zarządzanie projektami unijnymi. Teoria i praktyka, Difin, Warszawa.

Europejskie bezzwrotne źródła finansowania polityki regionalnej w Polsce, 2012, ed. W. Miemiec, UNIMEX, Wrocław.

Gliński P., Palska H., 1997, Cztery wymiary społecznej aktywności obywatelskiej, [in:] Elementy nowego tadu, ed. H. Domański, A. Rychard, Instytut Filozofii i Socjologii PAN, Warszawa.

Iwankiewicz-Rak B., 2011, Marketing w organizacjach pozarządowych - obszar zastosowań, Wydawnictwo Uniwersytetu Ekonomicznego we Wrocławiu, Wrocław.

Kolankiewicz E., Komorowska Z., Wasilewska M., 2008, Organizacje pozarzadowe a fundusze strukturalne. Podsumowanie wykorzystania funduszy strukturalnych przez organizacje pozarzadowe w Polsce w latach 2004-2006 i perspektywy na okres 2007-2013, Association for the Forum of Non-Governmental Initiatives, Warszawa.

Programowanie perspektywy finansowej 2014-2020, Umowa Partnerstwa, 2014, Ministerstwo Infrastruktury i Rozwoju, Warszawa.

Podstawowe fakty o organizacjach pozarzadowych 2012, Raport z badania 2012, 2013, Stowarzyszenie Klon/Jawor.

Przybylska-Maszner B., 2009, Rola organizacji pozarządowych w realizacji celów wynikajacych ze Strategii Lizbońskiej, Kancelaria Senatu, Warszawa.

Teisseyre P., Jak organizacje wykorzystaty fundusze unijne?, article published at www.ngo.pl [access 27.11.2014].

Umowa Partnerstwa, Programowanie perspektywy finansowej 2014-2020, Ministerstwo Infrastruktury i Rozwoju, Warszawa 2014

Wojtach A., Uwarunkowania zdolności absorpcyjnej funduszy unijnych $w$ administracji publicznej, article published at http://jmf.wzr.pl/pim/2012_3_1_32.pdf [access 27.11.2014].

www. euroNGO.pl [access 24.10.2014].

www.funduszeeuropejskie.gov.pl [access 10.11.2014].

\section{FUNDUSZE STRUKTURALNE A ROZWÓJ ORGANIZACJI NON-PROFIT}

Streszczenie: Prezentowany artykuł zawiera rozważania teoretyczne związane z wpływem funduszy strukturalnych na rozwój organizacji non-profit. Dostęp do tych środków powinien teoretycznie zapewnić tym podmiotom rozwój. Jednak praktyka pokazuje, że nie zawsze tak jest. Obserwujemy dynamikę rozwoju tego sektora i stale niewykorzystany potencjał społeczny. Organizacje te podlegają ciągłej presji ukierunkowanej na pełne wykorzystanie 
ich zasobów i wzrost efektywności podejmowanych działań. Jednak tempo ich rozwoju uzależnione jest w głównej mierze od środków przeznaczonych na ich rozwój, dlatego zasadne wydaje się dofinansowywanie działalności organizacji non-profit między innymi z funduszy strukturalnych. Środki te pozwalają na zdobycie doświadczenia, które wpływa korzystnie na ich rozwój. Jednak większość organizacji non-profit nie opiera swojego sukcesu na funduszach strukturalnych. Osoby zarządzające bardzo ostrożnie podchodzą do procesu pozyskiwania, wdrażania i rozliczania przedsięwzięć projektowych objętych wsparciem unijnym. Uważają, że proces ten nie zawsze kończy się sukcesem. Artykuł zwraca uwagę, że fundusze strukturalne mogą stanowić klucz do rozwoju organizacji non-profit, ale pod warunkiem, że ubieganie się o to wsparcie finansowe nie będzie przypadkowe i stanowić będzie zorganizowany ciąg działań.

Slowa kluczowe: organizacje non-profit, fundusze strukturalne, projekty unijne. 